\title{
免疫組織化学的手法による抗生物質の組織・細胞内分布·蓄積と毒性研究
}

\author{
藤原邦雄
}

\section{Distribution and Accumulation of Antibiotics in Cells and Tissues and Toxicity Studies by Immunocytochemistry}

\author{
Kunio FuJIWARA \\ Department of Applied Life Science, Faculty of Biotechnology and Life Science, \\ Sojo University, Ikeda 4-22-1, Kumamoto 860-0082, Japan
}

(Received January 24, 2011; Accepted March 16, 2011; Published online March 25, 2011)

\begin{abstract}
No true immunocytochemistry (ICC) for drugs nor its application to pharmacokinetic studies is available. Recently, our studies have shown that ICC for drugs is extremely useful for such studies by utilizing easy and safe techniques, and gives direct evidence of drug localization. We have therefore developed antibodies and a series of pretreatment conditions for the immunodetection of drugs and have localized sites of drug uptake or accumulation in several tissues of rats following the administration of drugs. This review describes preparation of anti-drug antibody, specificity of antibody, fixation of drug in situ in rat tissues and cells, treatment of paraffin section specimens prior to immunoreaction, precision, and their application to a variety of types of antibiotics anti-cancer anthracyclines daunorubicin, doxorubicin, and epirubicin, bleomycin analog peplomycin, antimicrobial agents gentamicin, and amoxicillin. ICC for the anti-cancer anthracyclines demonstrated that the drug accumulates in a characteristic pattern in the heart, liver, kidney, gastrointestinal tract, and hair follicles, which represent the sites targeted by the drug toxicity. Some, but not all, of these drug accumulations are associated with the induction of apoptosis. It was also noted that there are striking differences in accumulation among the anthracyclines in rat tissues, maybe contributing the mechanisms of the differences in anti-tumor activities of the anthracyclines. Both ICCs for gentamicin and peplomycin identified characteristic necrotic-like cells in the specific sites of the kidney, suggesting the sites are readily affected by some chemotherapeutic agents. ICC for amoxicillin demonstrated that the sites of the drug accumulation in small intestine, liver and kidney are closely correlated with the specific sites in which certain transporter systems for penicillin occur. Thus, an ICC method is a potential new tool for pharmacokinetic studies of wide variety types of drugs containing a primary amino group(s) in their molecules.
\end{abstract}

Key words_—immunocytochemistry; antibiotics; accumulation; side-effect; transporter; pharmacokinetics

\section{1.はじめに}

従来, 薬物の生体における薬効・毒性とそれに係 わる特定の組織細胞の薬物濃度との相関研究は報告 されていない. 原理的には，薬効・毒性を発揮する 細胞が特定され，その細胞での薬物濃度が把握でき れば，薬効や副作用をかなり正確に予想できると考 えられる。ささらにの薬物分布を適正に制御できれ ば，適切な効果が期待できると同時に，副作用を排 除することも可能と思われる. これら究極的な目的 を踏まえて, 薬物の組織細胞中の分布状態を知る方 法は，一般的にオートラジオグラフィーが行われ る.しかし, この方法は, 高感度で特異的ではある

崇城大学生物生命学部応用生命科学（干862-0082 熊本 市池田 4-22-1)

e-mail: fujiwara@life.sojo-u.ac.jp
が，アイソトープを使用することに伴う生来の欠点 を有している，また検出には，アイソトープを感光 させる等，いわゆる，間接法であり，煩雑で長時間

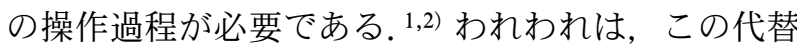
法として, 薬物の免疫組織化学的研究 (Immunocytochemistry, ICC) の開発を行ってきた。薬物の ICC は, 薬物の分布状態を, 直接, 顕微鏡下に検 出できるという長所を有し, 経済性, 簡便性, 安全 性等において，一般研究室，検査室に適した方法で あると思われる. ${ }^{3)}$ また，ICC は使用する抗体の特 異性に従って，基本的に薬物本体を検出できる．ま た感度においてもオートラジオグラフィーと遜色は ない.さらに, 実験操作には特殊な機器や熟練を必 要とせず，1-2 日の短期の操作で済むという大きな 利点がある。 
従来，薬物の免疫組織化学は組織細胞化学者によ つて確立された方法はなかった。筆者は本研究開発 に先立って，低分子有機塩基化合物である生体アミ ン Polyamines, 及び Histamine の ICC に従事し た。筆者は，これらハプテン化合物の特異 monoclonal 抗体を作製し, 光学的, 及び電顕学的免疫組 織化学的研究から, Polyamines はあらゆる細胞の ribosomes 上に存在すること, ${ }^{4-7)}$ また Histamine は, rat 胃の Enterochromaffin-like（ECL）細胞では細 胞質，及び特異顆粒の芯中に存在することを初めて 解明した. ${ }^{8,9)}$ 筆者はこれら低分子物質の研究方法 を，薬物の免疫組織化学に応用して，まず Anthracycline 系抗がん抗生物質 Daunorubicin（DR）

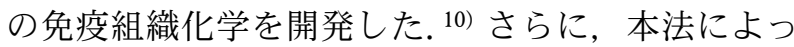
て，DR の副作用（心臟，腎臟，胃腸管障害，及び 脱毛症）とDR の細胞内蓄積性との間に重要な相関

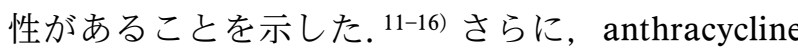
類似抗生物質, DR, doxorubicin（DX）及び epirubicin（ER）のICC の比較研究によって，これら 薬物の臟器蓄積性に顕著な差異があることを発見し た. ${ }^{14)}$ また，筆者らは，Bleomycin の第 2 世代 ana$\log$ peplomycin (PEP), ${ }^{17)}$ 及びアミノ配糖体抗生物 質 gentamicin (GM) の免疫組織化学を開発し，本 剂の腎臓毒性と薬物の特異的蓄積性との関連性を報

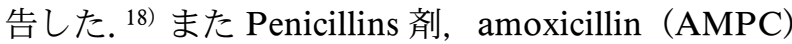
について, 十二指腸, 肝臓, 腎臓での薬物の分布と これら組織細胞中の Penicillin Transporters との密 接な相関性を報告した. ${ }^{19)}$ 本稿では，これらの例を 取り上げ，免疫組織化学の薬物動態学研究への応用 性について述べる。

\section{2. 抗体作製}

抗体は免疫組織化学に不可欠であり，その性質は 研究の成否を第一義的に左右する，ハプテン薬物に 対する抗体作製には，薬物を担体タンパク質に共有 結合した複合体（抗原）を合成する必要がある。結 合には主に，同反応性架橋剂グルタルアルデヒドや 水溶性カルボジイミドが用いられるが，原則的に薬 物の有機化学的反応性に合わせて，あらゆる結合法 が可能である。われわれは Anthracycline 系抗がん 抗生物質 Daunorubicin (DR), 11) 第 2 世代 Bleomycin 類似体 Peplomycin (PEP), ${ }^{18)}$ 及びアミノ配糖 体抗生物質 Gentamicin (GM) ${ }^{17)}$ の場合には, これら 抗生物質と牛血清アルブミン（BSA）との結合に,
異反応性架橋剂 $N$ - ( $\gamma$-maleimidobutyryloxy) succinimide (GMBS) ${ }^{20-23)}$ を使用している。本架橋剂は 薬物，あるいはタンパク質の自己縮合や薬物一タン パク質間の重合反応を起こさず，均質なハプテン一 タンパク質複合体が得られる点で優れている。 また 第 3 世代 Penicillin 剂の Amoxicillin (AMPC) ${ }^{19)}$ の 場合には，glutaraldehyde（GA）を用いて, BSA に結合させた。われわれはこれらタンパク質複合体 を用いて，rabbit，あるいは mice を免疫化し，抗 薬物血清, ${ }^{17,19)}$ さらに，モノクロナル抗体（mAb） を作製して, ${ }^{11,18)}$ それぞれの薬物の免疫組織化学に 使用した.

なお，われわれの経験によると，生体にとつて異 物薬物であっても，化学構造が特殊で，分子量が極 端に小さい場合は，抗体は得られない場合がある (例えば，アレンドロン酸)。このような場合には, オートラジオグラフィーが唯一の方法になると思わ れる。

\section{3. 特異性}

抗体の特異性を正確に評価することは，いかなる 免疫化学においても重要なプロセスの 1 つである が，すべての抗原に関して，免疫組織化学的に要求 を満たす検定法は知られていない。ろ紙やニトロセ ルロース膜にアルデヒド固定を取り入れたイムノブ ロットテストは，試料が膜の中に埋め込まれ，抗体 との反応が起こり難いことがあり，抗体特異性の定 量的解析には十分ではない。 また，低分子ペプチド や薬物の場合，一般的に ELISA 法が使用される. これはマイクロタイタープレートに固層化したタン パク質一薬物複合体と, free の薬物とを一定量の抗 体に対して競合させる方法であり，定量的な抗体特 異性の解析が可能である. しかし，極低分子量（分 子量，約 200 以下）の薬物になると，free の薬物と 抗体との結合親和性が，タンパク質一薬物複合体と の場合よりも極端に弱くなり，したがって，この方 法では，薬物濃度依存的な標準曲線が得られない場 合がある。このような極低分子量薬物の場合，筆者 らは以下のような ELISA Binding Test を使用して いる. ${ }^{24)}$ すなわち，マイクロタイタープレートをポ リ-L-リジン，あるいは BSA でコーティングし，つ いで GA で活性化した後，検定されるハプテン化 合物をアミノ基を介して共有結合で濃度依存的に結 合させる。このようにして調製した固層抗原プレー 
卜を indirect immunoperoxidase 法による免疫反応 を行い，プレートに結合した抗体量を peroxidase 活性をマーカーに用いて測定し，半定量的に抗体の 特異性を解析する.

Anti-DR mAbs, ADM-1-11 の特異性11)：本抗体 は免疫化に用いた DR のみならず，Anthracycline 類縁抗生物質の Doxorubicin (DX), 及び Epirubicin（ER）とも同程度の交差反応性を示した（ELISA 法).

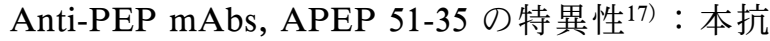
体は免疫化に用いた PEP に monospecific であり, 第 1 世代抗生物質 Bleomycin とは交差反応しなか った (ELISA 法).

Anti-GM 血清の特異性 ${ }^{17)}$ : 本抗体は免疫化に用 いた GM に特異的であり，アミノ配糖体類縁抗生 物質の Kanamycin, Amikacin, Tobramycin，及び Streptomycin とは全く反応しなかった(ELISA 法).

Anti-AMPC 血清の特異性 ${ }^{19)}$ ：本抗体は免疫化に 用いた AMPC と類縁 Penicillin 剂の Ampicillin (ABPC) に同程度の交差反応性を示した。一方, bacampicillin 及び Cephalexin とはそれぞれ 15\%， $13 \%$ と弱く反応したが， cefaclor 及び cefminox と は全く反応しなかった（ELISA Binding Test）。

\section{4. 組織の固定化}

本点は免疫組織化学において最も重要なプロセス の 1 つである. 組織の形態を保持し，抗原薬物を分 布したその場に不動化するためには，一般に敏速か つ完全な固定化が必要である。しかし，この固定化 条件とは対照的に，抗原性を保持し，また免疫試薬 が組織細胞中に適切に入り込むためには，できる限 り，弱い固定化条件が望まれる。したがって，実際 の固定化に際しては，これら相反する条件の中から 妥協点を探さなければならない。このことは，薬物 のように容易に再分布し易い低分子化合物の際に, 特に重要である，固定剤としては，強力な共有結合 性の Karnovsky 固定剂（glutaraldehyde と paraformaldehyde との混合液), 1-5\% glutaraldehyde (GA), あるいは $5 \%$ アクロレイン溶液が適している。これ によって，薬物を細胞中のその場のタンパク質に （薬物分子中の 1 級アミノ基を介して）共有結合で 固定化することができる，さらに，固定化操作は， 動物の心臓（左心室）から直接，固定液を毛細血管 を通して，全身に灌流させ，動物全体を瞬時に固定
化する，いわゆる，灌流固定法が最良である。これ らの実験を通じて，固定化の至適条件：固定液の種 類，濃度，容量，速度，固定時間を決定する，さら に，後固定の条件を細かく設定することも，低分子 化合物の免疫組織化学の場合は特に重要である.

\section{5. 包埋, 及び薄切}

通常，固定化された組織片は大別して，パラフィ ン包埋，あるいは凍結組織包埋剂（OCT compound）を用いて急速に凍結する，組織構造保存の 点では前者が勝るが，抗原性の保存の点では後者が 優れている．われわれは光学顕微鏡レベルの研究で は専ら, Merk 社の Histosec 60 pastilles を用いて, パラフィン包埋切片 $(5 \mu \mathrm{m})$ を作製している.

\section{6. 組織・細胞の免疫反応前処理}

脱パラ，あるいは脱包埋剂（OCT compound な ど）処理した切片を直接，抗体と反応させても，特 殊な場合を除き，一般に，抗原一抗体反応は起こら ない。そそれは固定化の段階を含めて，薬物が細胞内 において，いろいろな遮蔽効果を受けるためであ る。したがって，切片は免疫反応に先立ち，下記の 操作が必要である.

過酸化水素処理：筆者らは薬物の anthracyclines (DX, DR, ER) , GM, PEP の場合に，比較的高濃度 の $\mathrm{H}_{2} \mathrm{O}_{2}(\sim 6 \%), 30$ 分処理によって, 内因性 peroxidase 活性を阻害し，かつ著しい抗原性の賦活 化現象を見い出している．しかし，その機序は詳細 には分かっていない. ${ }^{12}$

塩酸処理 : 切片の塩酸 $(1-2 N), 30$ 分処理によ つて，2 本鎖 DNA を解離させることによって, DNA 中に取り込まれた薬物の免疫反応を可能にす る。本法は増殖性細胞に取り込まれた 5-bromodeoxyuridine（BrdU）の同定法に使用されている. ${ }^{25-27)}$

タンパク質分解酵素処理：GA による固定の場合 は，対象となる薬物を細胞内のタンパク質に架橋す ると同時に，他のタンパク質分子同士間の架橋 intermolecular cross-linkage が抗原の周りに起こり, 抗体が抗原薬物のところまで浸透でき難くなる。こ のような場合は, タンパク質分解酵素処理によっ て，劇的な抗原性の賦活化 unmasking 現象が認め られる。筆者らは protease (Type XXIV: Bacterial, Sigma-Aldrich）を用いて，広範に protease 消化条 件を検討している. ${ }^{17-19)}$

水素化ホウ素ナトリウム処理：一級アミノ基を有 
する薬物，あるいは生体アミンの in situ での夕ン パク質との固定化反応においては, 単に GA の aldehyde 基とタンパク質の amino 基との間の Schiff 塩基形成反応のみではない. ほかに Michaelis 反応 を含めて，GA との反応は複雑のようである。 $\mathrm{NaBH}_{4}$ は Schiff 塩基を還元して安定化するのみな らず，in situ に残存する GA の一方の aldehyde 基 をアルコール基に変換する。これは非特異的免疫反 応を除き，最終的な DAB（3,3'-Diaminobenzidine 4HCl）での発色反応の background を抑える上で 重要である。しかし anthracycline 系抗生物質な ぞ，薬物自身が $\mathrm{NaBH}_{4}$ で還元される場合は，抗原 性を消失することがあるので， $\mathrm{NaBH}_{4}$ の適用濃度 は厳密に検討する必要がある. ${ }^{10-12,14-18)}$

\section{7. 感度と正確性}

以上述べた方法の感度と正確性は，今回取り扱つ た薬物に対する組織細胞内分布を調べる方法がない ので，直接的に評価することはできない，免疫組織 化学的方法には固定液の使用が不可欠である。した がって，固定操作の間に，薬物が再分布したり，消 失したりする恐れがあり，正確性や感度の低下が危 惧される。しかし，今回用いた十分に強い固定作用 を有する固定剂を用いて灌流固定を行えば，細胞内 の薬物は in situ に保持され, 組織中の同種の細胞 に再現性よく局在化する。これは in situでの GA と薬物，あるいはタンパク質との反応が，薬物の移 動速度より，十分に速いことを示していると思われ る。事実，これらの固定液は低分子化合物で内因性 生体アミン (GABA, ${ }^{28)}$ グルタミン酸, ${ }^{29)}$ ヒスタミ ン, ${ }^{7-9,30)}$ ドパミン, ${ }^{31)}$ グリシン, ${ }^{32)}$ ポリアミン $\left.{ }^{3-5)}\right)$ の免疫組織化学研究に広範に使用されており，その 有用性が証明されている。放射性同位元素でラベル 化した薬物を用いるオートラジオグラフィーでの検 出には，アイソトープを感光させる場合，切片と感 光乳剂の接着には，特に注意を払う必要がある。ま た, 細胞分画法による化学的測定法も, 操作中に薬 物の再分布が起こり易く，有用性は低い.

\section{8. 免疫組織化学 (Immunocytochemistry, ICC)}

8-1. Anthracyclines daunorubicin (DR), doxorubicin (DX), 及び epirubicin（ER）この 3 剂 はわずかな化学構造の違いにもかかわらず, 臨床適 用や薬動力学パラメー夕は大きく異なっている.す なわち，DX, ${ }^{33)}$ 及び $\mathrm{ER}^{34)}$ は白血病を含む多種の
固形がんに広範に有効であるが，DR は専ら白血病 に使用される。. ${ }^{35)}$ また Anthracyclines 系薬物の重大 な副作用は心毒性であり，毛包，胃腸，及び腎臓に 対しても毒性を示す。筆者らは，これら 3 剂と同等 の反応性を示す monoclonal 抗体（ADM-1-11）を ICC に使用して, ${ }^{11)}$ Rat 組織・細胞での薬物の分布 を経時的に検討した．胃腸管 ${ }^{14)}$ ：細胞内での薬物の 蓄積は，薬物の取り込み，排出，及び薬物の代謝が 総合的に反映すると思われる. DR i.v. one shot 投 与後 2 時間の胃腸管では, 薬物は杯細胞の mucin goblets を除いて，すべての上皮細胞（吸収上皮細 胞，腸陰窩細胞，Paneth 細胞，十二指腸腺細胞な ぞ）にほぼ均一に分布した [Figs. 1 (a)-(d)]。し かし，16 時間後には, 薬物は大・小腸の表層上皮 から消失したが，陰窩の腺細胞には残存した [Fig. 1 (e) ］。小腸や結腸上皮の小皮縁には，anthracyclines を基質とするATP-binding cassette (ABC) transport protein のP-糖タンパク質が存在してお り, ${ }^{36-38)}$ 上皮細胞の DR は管腔側に排出される可能 性が考えられる。また，Apoptosis は，DR を取り 込むすべての細胞に起こるのではなく，小腸，結腸 の陰窩の中央付近や，胃の侠部付近の細胞に観察さ れた [Figs. 1(f) and (g)]。これらの部位は主に, 未成熟細胞からなる細胞増殖帯，あるいは precursor cell zone に相当する. ${ }^{39)}$ したがって，Apoptosis は Thakkar と Potten ${ }^{40,41)}$ が小腸での apoptosis 研 究で報告しているように, 幹細胞や前遷移細胞 （early transit cells）に特異的に生じていると思われ る。心臓12：DR は心筋細胞の核質，また細胞質中 の小顆粒中に分布し，しかも顆粒は心筋細胞の長軸 に沿って一直線上に配列した [Fig. $1(\mathrm{~g})]$ 。また， 胃腸管の平滑筋・横紋筋細胞においても，薬物は 核, 及び小顆粒中に分布した。これら小顆粒が心臓 毒性に係わるかどうかはいまだ不明である。なお，

ADM-1-11 抗体をDR $(10 \mu \mathrm{g} / \mathrm{ml})$ で前吸収すると 免疫反応は完全に消失した [Fig. 1(h) ]. 毛包 ${ }^{15)}$ : DR 投与 24 時間で, 薬物は, 母基細胞の subpopulationに出現した特徵的な核と外根鞘細胞に蓄積し た [Fig. 2(a)]。また，これら細胞には, programmed cell death (PCD) が出現し [Fig. 2(b)], 投 与 5 日後まで検出された。 しかし, 毛包の幹細胞が 存在する Bulge 野, ${ }^{42-44)}$ 及び毛乳頭の間葉細胞には PCD を生じなかった。事実，間葉細胞には DRの 

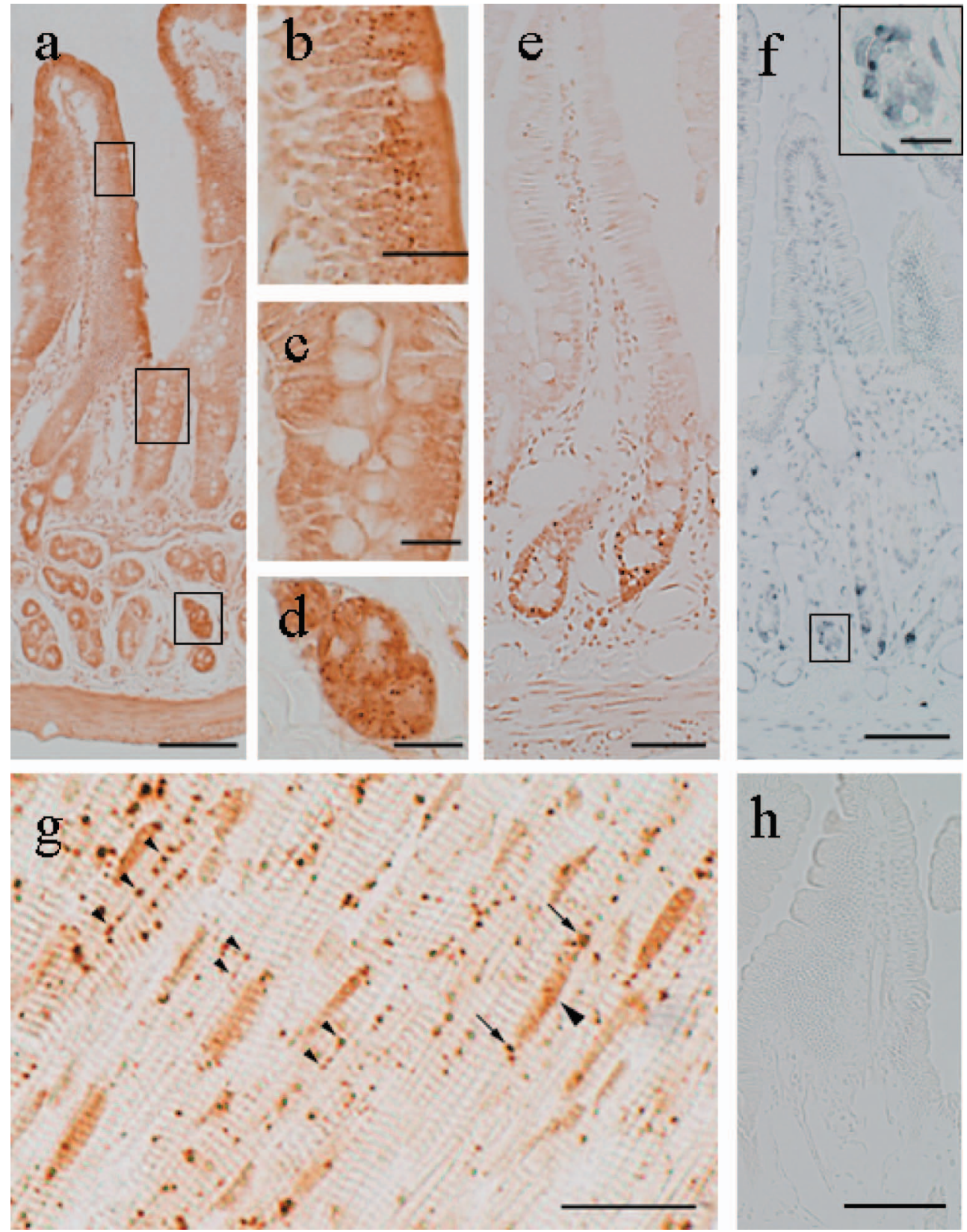

Fig. 1. Immunocytochemical Detection of Daunorubicin (DR) or Apoptic Cells ${ }^{12,14}$

a-e Immunocytochemistry (indirect immunoperoxidase method) for DR in the gastrointestinal tract of rats after a single i.v. injection of DR. Duodenum at $2 \mathrm{~h}$ (a-d) and $16 \mathrm{~h} \mathrm{(e)} \mathrm{after} \mathrm{the} \mathrm{injection:} \mathrm{a} \mathrm{Strong} \mathrm{DR} \mathrm{immunoreactivity} \mathrm{was} \mathrm{seen} \mathrm{equally} \mathrm{in} \mathrm{whole} \mathrm{cells} \mathrm{of} \mathrm{the} \mathrm{tissues} \mathrm{except} \mathrm{for} \mathrm{the} \mathrm{apical} \mathrm{cytoplasm} \mathrm{of} \mathrm{the} \mathrm{goblet} \mathrm{cells.}$ Higher magnification of the three framed areas i.e., the absorptive cells (b), crypt cells $(\mathbf{c})$, and duodenal gland cells (d) in a shows that DR accumulated both in the nuclei and cytoplasm where it occurs in the form of minute granules. e Note immunoreactivity was little or not evident in the absorptive cells, but moderate in other cell types including crypt cells, smooth muscle cells, interstitial cells and endothelial cells. The granules in the crypts looked larger than those in $\mathbf{b}, \mathbf{c}$, or $\mathbf{d}$. f Immunocytochemical detection of apoptotic cells (TUNEL method) in the gastrointestinal tracts of rats after a single i.v. injection of DR. Duodenum at $16 \mathrm{~h}$ after the injection: Apoptotic cells were localized only in the crypt of the tissues. The framed area of the crypt in $\mathbf{f}$ was magnified and inserted. $\mathbf{g}$ Immunocytochemistry of DR uptake in the cardiac muscle cells of rats injected i.v. with DR. Cardiac cells in longitudinal section immunostained by ICC staining occurs in nuclei (large arrowheads) and in the sarcoplasm in the form of tiny granules. Note that most of the granules occur in parallel arrays between the myofiblirils (small arrowheads). $\mathbf{h}$ The staining (seen in a) was completely abolished by absorption of the mAb with DR at a concentration of $10 \mu \mathrm{g} / \mathrm{ml}$. Bars $\mathbf{a}, \mathbf{e}, \mathbf{f}, \mathbf{h} 20 \mu \mathrm{m} ; \mathbf{b}-\mathbf{d}, \mathbf{g} 100 \mu \mathrm{m}$.

取り込みを認めなかった。新毛の開始に母基細胞は 重要な役割を果たすと考えられている. ${ }^{45-47) ~ ま た, ~}$ 化学療法の停止によって, 新毛が再生することは, 毛乳頭に PCD が生じないこととよく符合してい る。また二重染色法で, DR-陽性母基細胞核の一部
に Tunel 陽性反応が観察された [Fig. 2(c) ]. 14) ま た免疫電顕法によって，2 種の異なる形態を有する DR 陽性細胞，すなわち classical apoptosis (PCD type 1) ${ }^{48)}$ と autophagic cell death (PCD type 2) ${ }^{49-51)}$ が証明された。腎臓16)：上記 3 剂は，いずれも，投 


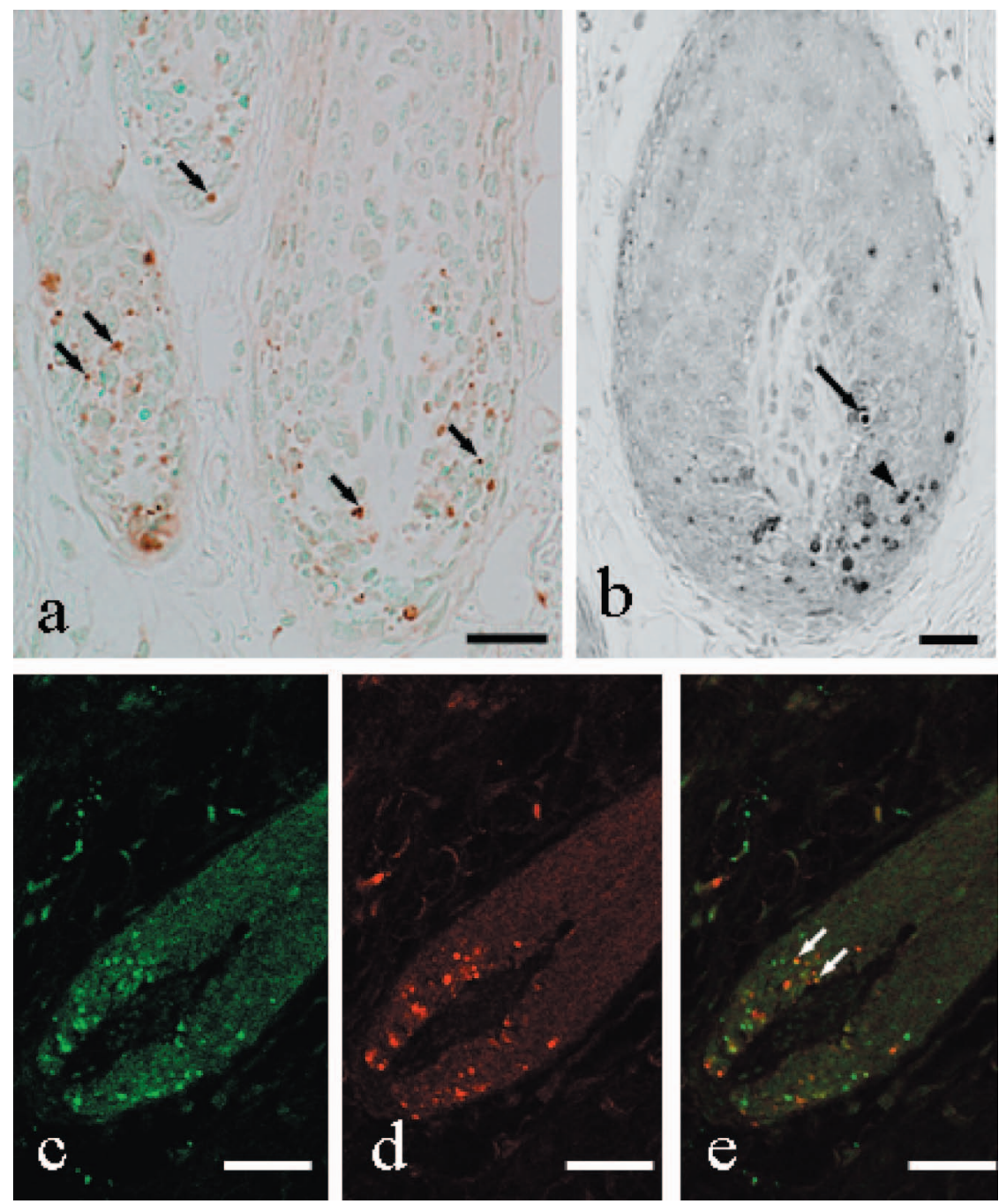

Fig. 2. Immunocytochemical Detection of Daunorubicin (DR) or Apoptic Cells in Rat Hair Follicles ${ }^{15)}$

a DR uptake in cells of rat hair follicles. Twenty four $\mathrm{h}$ after injection, strong immunoreactivity for DR was observed in nuclei of a subpopulation of matrix cells (arrows). No staining was detected in cells of the dermal hair papilla. A variety of globular or granular nuclei existed in the matrix, although no such nuclei did $2 \mathrm{~h}$ after DR injection (data not shown). b Detection of cells undergoing programmed cell death (PCD) by the TUNEL method. By $24 \mathrm{~h}$ after injection, numerous TUNEL-positive cells occur in the matrix, whereas none are seen in the dermal hair papilla. Note that a TUNELpositive cell is surrounded by clear halos and that others contain fragmented nuclei (arrowhead). c-e Double immunofluorescence staining for DR (c; green) and apoptotic cells (d; TUNEL reaction; red) $24 \mathrm{~h}$ after DR-injection. A merged image is shown in e. Note partial co-localization (arrows) of DR and TUNEL positivity. Bars a-e $25 \mu \mathrm{m}$.

与後 2 時間では, 腎小体を形成する細胞群（podocytes, Goormaghtigh's cells, glomerular capillary, parietal epithelium cells など), 刷子縁膜を含む近位 尿細管細胞，遠位尿細管・集合管細胞，内皮細胞， 平滑筋細胞に同様なパターンで分布した：すなわ ち，投与 2 時間では，S1, S2 の近位尿細管細胞に は中程度の薬物が分布し, S3 部位には低濃度が分 布した（Fig. 3)。一方，遠位尿細管・集合管細胞， podocytes, parietal epithelium cells, 内皮細胞, 及び 平滑筋には高濃度の薬物が分布した。投与 16 時間 になると，DR 蓄積量はどの細胞においても，他の 2 剂（DX や $\mathrm{ER}$ ) よりも低濃度に減少した。さら
に，5日目になると，DR はもはや腎臓のどの細胞 にも検出されなかった。一方, DX と ER はなお相 当の薬剂量 $(\mathrm{DX}>\mathrm{ER})$ が残存した. ${ }^{16)}$ なお, 3 剂 における蓄積性の差異は他の臟器 [胃, 膵臓, 毛 胞, 肝臟 (Fujiwara K., Shin M., Miyazaki T., 掲載

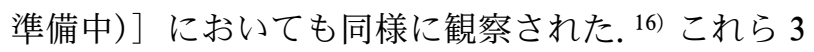
剂の差異が薬物の抗がんスペクトルの差異, あるい は毒性に関係して可能性が高い。なお， 3 剂とも に, 近位尿細管 $\mathrm{S} 1, \mathrm{~S} 2$ の細胞質からの薬物の減少 が顕著であった. S1, S2 の尿細管の微絨毛には薬 物の輸送に係わる $\mathrm{P}$-糖タンパク質が局在すること から, ${ }^{52,53)}$ これら薬物の尿細管分泌に積極的に係わ 


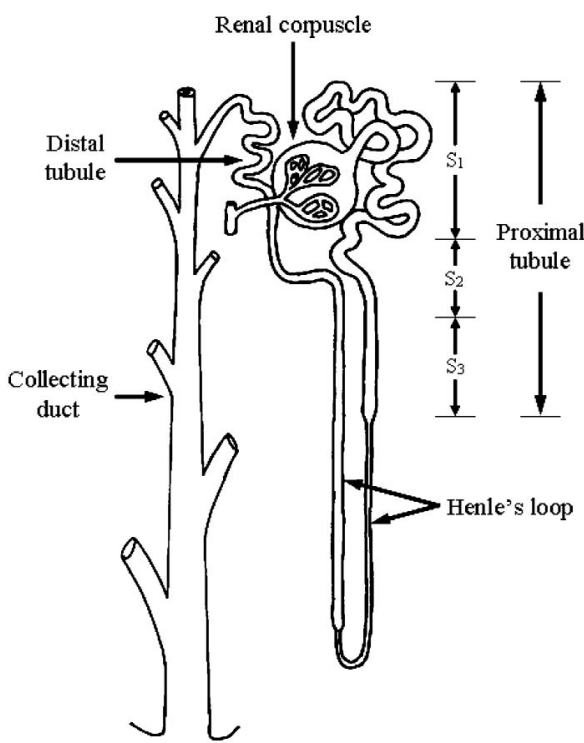

Fig. 3. Schematic Representation of a Nephron ${ }^{18}$

Three ultrastructurally distinct segments (S1, S2, and S3) are identifiable in the proximal tubule.

る可能性がある. 肝臓 (Fujiwara K., Shin M., Miyazaki T., 掲載準備中)：DX 投与 2 時間の肝臓では, DR は肝細胞の細胞質，核中に，また毛細胆管に沿 つて，顆粒状の特徵的な薬物の分布を示した，正常 rat の毛細胆管の細胞膜には，P-糖タンパク質が局 在している. ${ }^{54,55)}$ ICC の結果は本薬物の排泄に，当 該 transporter が in situで係わることを示唆してい る。また DX は sinusoids の内皮細胞，胆管細胞・ 胆管の管腔表面，及び Kupffer 細胞に分布した。こ れらは血流からの DX の取り込み，排泄，及び貧 食等を示している.さらに，Glisson's capsule の近 くの sinusoids 中には, 薬物が蓄積した未同定の大 型細胞が出現した。

\section{8-2. Gentamicin (GM) ${ }^{18)}$ 本剂は緑膿菌に有} 効であるが，アミノグリコシド抗生物質の中でも， 聴覚毒性は顕著である。また腎臟毒性があり, autoradiography を始め，広範な研究がなされてい る. ${ }^{54-57)} \mathrm{GM}$ 投与 12 時間で，薬物は近位尿細管の $\mathrm{S} 1, \mathrm{~S} 2$, 及び S3 部位の細胞質に, また遠位尿細管と 集合管細胞に検出された [Figs. 3 and $4($ a $)-(d)$ ]. また投与 1 時間では，近位尿細管微絨毛にも特徵的 に薬物が検出された [Fig. 4(e)]。また，S1，S2の 近位尿細管では，細胞質中の顆粒に顕著な薬物の取 り込みがみられた [Figs. 4(c) and (f)]。これは従 来の autoradiography ${ }^{58,59)}$ や金コロイド法60)による
研究結果と一致しており，薬物は endocytosis によ って，微絨毛から再吸収され，近位細胞中の lysosome に蓄積されていると思われる。ささらに，われ われはオートラジオグラフィーでは検出できなかつ た微量の $\mathrm{GM}$ が $\mathrm{S} 3$ 部位に蓄積することを示した [Fig. 4(b) ]. ${ }^{61)}$ また遠位，及び集合管細胞には，薬 物で膨化した necrosis 様細胞が検出された [Figs. 4 (a) and (b) ]。以上から，GM による腎臟毒性は， 従来から知られている近位尿細管細胞におけるライ ソゾームの phospholipidosis ${ }^{58-61)}$ のみならず，遠位 尿細管・集合管細胞にも広範に起きていると思われ る。これは，Parsons ら ${ }^{62)}$ の研究（GM によって引 き起こされる hypercalciurea は遠位尿細管でのカル シウムの再吸収の減少によるという）結果からも支 持される.

8-3. Peplomycin（PEP） 17) 本剂は頭部及び 頝部 carcinoma に有効であり，Bleomycinの重篤な 肺線維症を軽減したものとして開発された。 ${ }^{63)} し か$ し，なお肺，腎臓，肝臓，心臟毒性が知られてい る. ${ }^{64)}$ PEP i.v. 投与 2 時間で，薬物は近位尿細管・ 細胞質の不規則な顆粒中，及び微絨毛上に観察され た。この分布は GM の分布パターンと酷似し, ${ }^{17)}$ か つ顆粒中のPEP 抗原の検出には，試料を強い条件 下に protease 前処理する必要があった。以上から 不規則形顆粒は lysosomes であると思われる。また， PEP の消失は早く, 24 時間後には近位尿細管には ほとんど，検出されない。本点は，約 1 力月間，長 く残留する GM とは顕著に異なっている（未発 表)。また，遠位尿細管と集合管細胞中には，薬物 によって膨化した necrosis 様細胞が検出された. GM と PEP の ICC の結果から，遠位尿細管・集合 管細胞には，薬物によって，影響を受け易い細胞が 存在すると思われる。

8-4. Amoxicillin (AMPC) 19) 本剂は第 3 世 代 penicillin 剂で，グラム陽性菌とグラム陰性菌の 一部に有効であり，中程度の抗菌スペクトルを示 す。またへリコバクター・ピロリ菌の駆除薬として 併用される。近年， penicillin 剤に対する種々の transporters が分子レベルで解明されている. ${ }^{65)}$ 小 腸：AMPC 内服・単回投与 3 時間で，高濃度の AMPC が villi の吸収上皮細胞の核，細胞質，及び 微絨毛膜に観察されたが，杯細胞や陰窩細胞には全 く観察されなかった [Figs. 5(a) and (b)]．微絨毛 

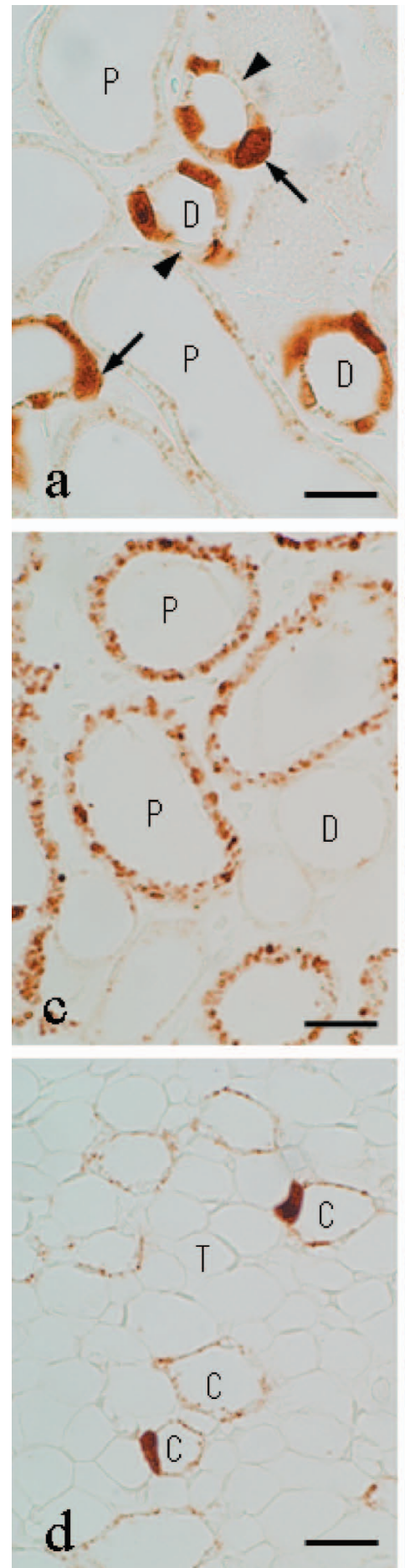
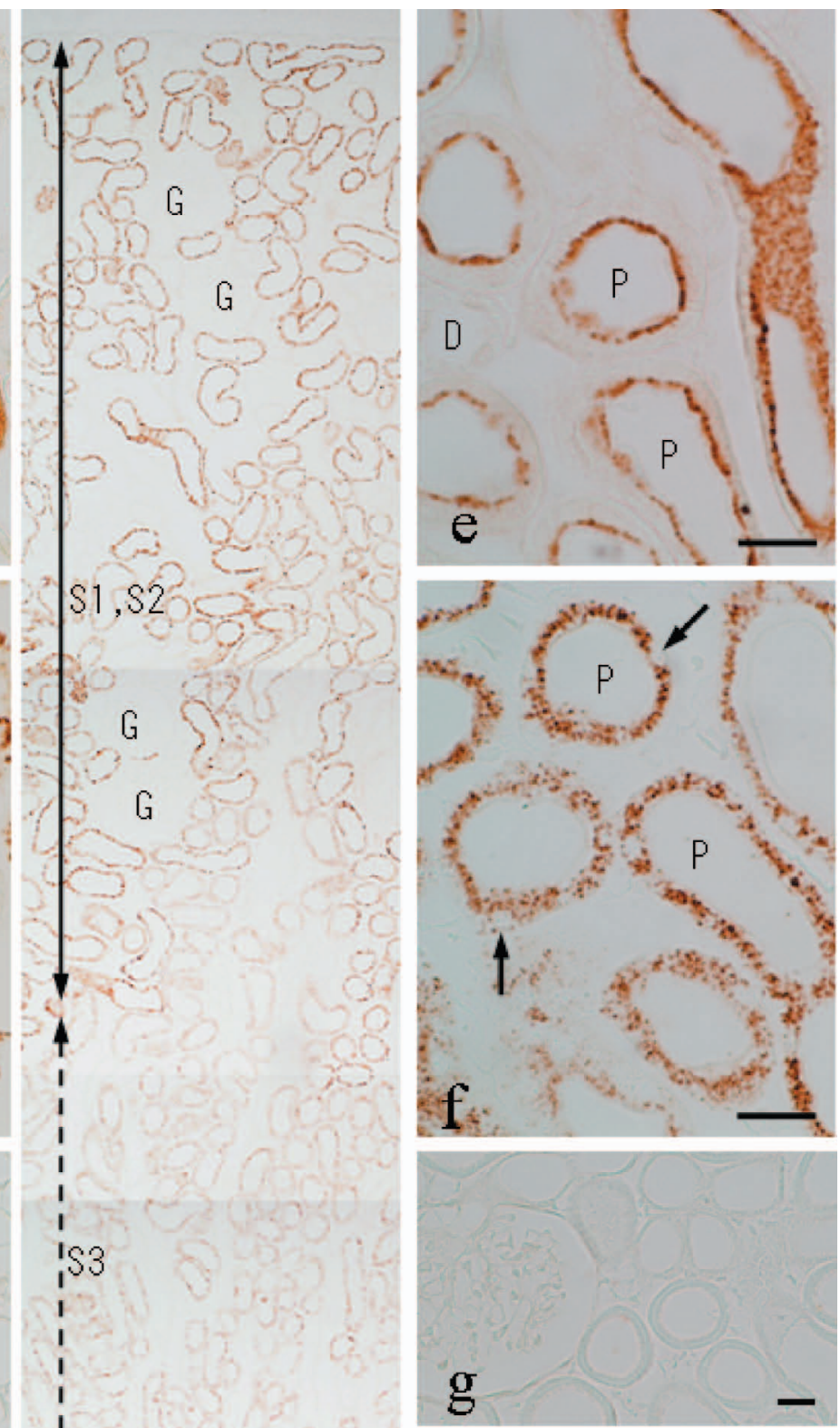

b

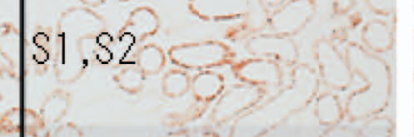

G
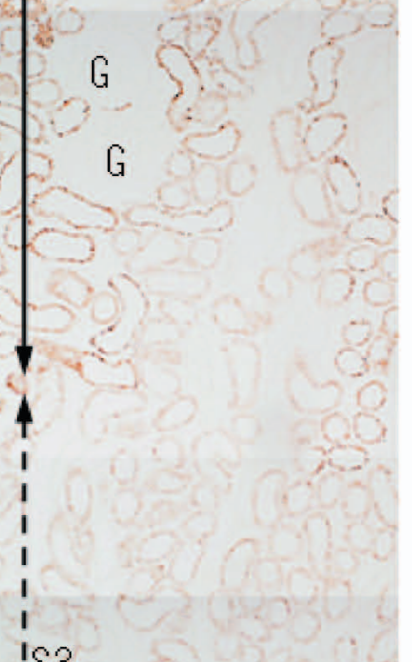

IS3

I

1
1
1

i

1
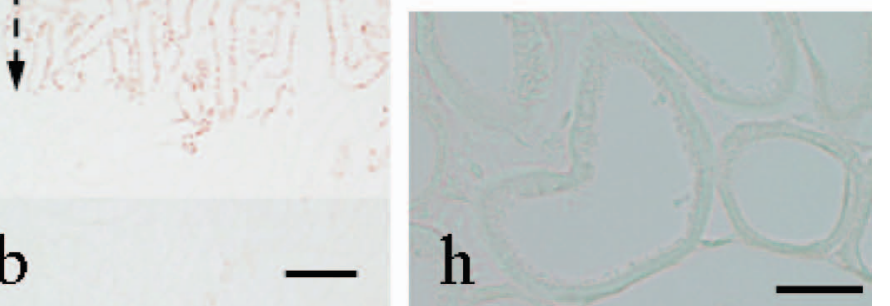

Fig. 4. Immunocytochemical Detection of Gentamicin (GM) in Rat Kidney ${ }^{18)}$

$\mathbf{a}$-h Immunostaining for GM in the kidneys of rats $12 \mathrm{~h}(\mathbf{a}$ to $\mathbf{d}, \mathbf{g}$, and $\mathbf{h}$ ) or $1 \mathrm{~h}$ (e and $\mathbf{f})$ after GM injection. GM ICC was carried out following digestion of the sections with $0.004 \%$ protease at $30^{\circ} \mathrm{C}$ for $15 \mathrm{~min}(\mathbf{a}$ and $\mathbf{e}), 30 \mathrm{~min}(\mathrm{~d})$, or $2 \mathrm{~h} \mathrm{(b,} \mathrm{c,} \mathrm{and} \mathbf{f}$ to $\left.\mathbf{~ h}\right)$. a Twelve hours after GM injection (16 mg/kg), the nuclei as well as the cytoplasm of cells of the distal convoluted tubules (D) are immunostained for GM. Note that heavily stained cells are swollen (arrows) and that adjacent cells are virtually unstained (arrowheads). Only very slight immunostaining was observed in the proximal tubules (P). b Renal cortex. Immunostaining is strong in the S1 and S2 segments of the proximal tubules and weak in the S3 segment (medullary portions of the straight proximal tubule). Almost no immunoreaction was observed in the glomeruli (G) or the distal tubules. The S3 segment was identifiable by the presence of periodic acid-Schiff-positive brush borders. $\mathbf{c}$ Higher magnification of the renal cortex. Note strong immunostaining of cytoplasmic granules in proximal tubule cells and virtually no staining in the distal tubules. $\mathbf{d}$ Swollen cells that are heavily immunopositive for GM are present in the collecting ducts (C). T, thin limb of Henle's loop or blood capillary. e and f Strong immunostaining occurs on microvilli and apical regions of the cytoplasm of the proximal tubules $1 \mathrm{~h}$ after injection of GM, while there is almost no staining of the distal tubules. $\mathbf{f}$ Note strong immunostaining of cytoplasmic granules, but not of nuclei (arrows), in cells of the proximal tubules. $\mathrm{g}$ No immunoreaction is evident in the renal cortex cells of control rats injected with saline. $\mathbf{h}$ The staining was completely abolished by absorption of the anti-GM serum with GM-GMBS-BSA. Bars $\mathbf{a}$ and $\mathbf{c}$ to $\mathbf{h} 20 \mu \mathrm{m}$; $\mathbf{b}$ $100 \mu \mathrm{m}$. 

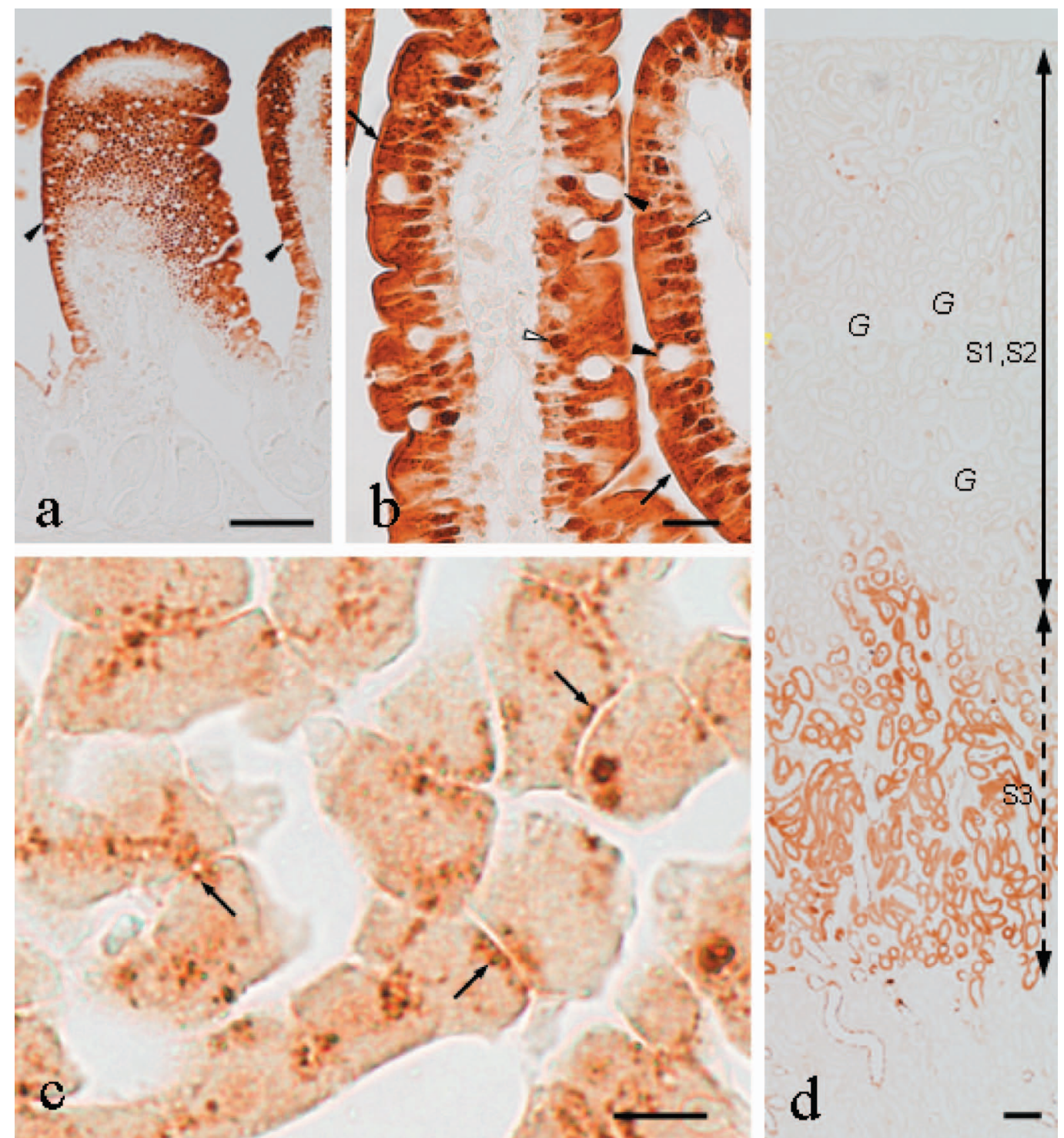

Fig. 5. Immunocytochemical Detetion of Amoxicillin (AMPC) ${ }^{19}$

a, b Immunostaining for AMPC in the three organs of AMPC-administered rats. Rats were orally administered AMPC at $60 \mathrm{mg} / \mathrm{kg}$, and then sacrificed $3 \mathrm{~h}$ later. AMPC ICC was carried out following digestion of sections with protease at $0.001 \%$ at $30^{\circ} \mathrm{C}$ for $1 \mathrm{~h}$. a Jejunum: Strong staining occurred in the microvilli $($ arrows), in the cytoplasm, and in the nuclei (open arrowheads) of the absorptive epithelial cells, but not in the goblet cells (closed arrowheads). b Jejunum (higher magnification). Strong staining occurred in the microvilli (arrows), in the cytoplasm, and in the nuclei (open arrowheads) of the absorptive epithelial cells but not in the goblet cells (closed arrowheads). Very weak staining occurred in unidentified cells in the lamina propria mucosae. c Liver (higher magnification): Sections were digested with $0.006 \%$ protease for $2 \mathrm{~h}$ prior to immunoreaction. Note strong staining in the small spots (arrows) lining along to the bile capillaries. $\mathrm{d}$ Kidney: AMPC were orally administered AMPC at $15 \mathrm{mg} / \mathrm{kg}$, and then sacrificed $3 \mathrm{~h}$ later. AMPC ICC was carried out following digestion of sections with protease at 0.006 $\%$ at $30^{\circ} \mathrm{C}$ for $1 \mathrm{~h}$. Renal cortex (lower magnification). Staining pattern was characteristic of the fact that strong staining occurred extensively in the S3 segment cells of the proximal tubules. Bars a, d $100 \mu \mathrm{m} ; \mathbf{b}, \mathbf{c} 20 \mu \mathrm{m}$.

\section{中には薬物の輸送に係わる transporter PEPT1 が存} 在する. ${ }^{66-68)}$ ICC の結果は, 本 transporter が AMPC (dipeptide-like 薬物) の取り込みに係わることを示 唆している。.また，筆者らは AMPC は，経細胞的 透過機序によって吸収上皮細胞から吸収されること を証明した。肝臓： $\beta$-lactam 剂の大部分は尿中 に, しかし一部の誘導体は胆汁中に排泄され る. ${ }^{69,70)}$ 薬物投与 3 時間で, AMPC は肝細胞の毛細
胆管に沿って，特徵的な顆粒状の分布を示した [Fig. $5(\mathrm{c})]$ 。また筆者らは，AMPC が毛細胆管， 介在部，ついで小葉間胆管へと続く胆汁排泄経路に 沿った管腔表面に，吸着している AMPC を証明し た．肝細胞の洞様毛細血管細胞質膜には，有機ア二 オントランスポーター (OAT $)^{71,72) ~ や ~ s o d i u m-~}$ dependent phosphate transport protein $(N P T 1)^{73,74)}$ が存在する，前者は血流から薬物の取り込みを，後 
者は肝細胞から血液側へと薬物の排泄を介在すると 考えられる。また，毛細胆管膜には， multidrug resistance-associated protein (Mrp2) ${ }^{75-77)}$ が高濃度に 発現し，薬物の胆汁排泄に係わると考えられている. ICC の結果は，肝臓組織 in situ で，Mrp2 が機能し ていることを強く示唆している，また，胆管からの 薬物の排泄は早く，6時間後には肝臓のいかなる細 胞にも薬物は検出されなかった。腎臓：尿細管にお いて， $\beta$-lactam 剂は分泌，あるいは再吸収を受け る. ${ }^{78)} \mathrm{AMPC}$ は，近位尿細管中，特に S3 部位に多 量分布した [Figs. 3 and $5(\mathrm{~d})]$ 。 また，24 時間後 には，AMPC の大部分が消失するが，S3 部位に は，なお，その微量が検出された。 basolateral membrane からの薬物の取り込みは Transporters OAT1，OAT2，OAT3 が考えられる. ${ }^{79,80)}$ また糸球 体濾液からの薬物の再吸収には，近位尿細管の $\mathrm{S} 1$, 及び S3 に, $\mathrm{H}^{+} /$peptide cotransporters PEPT1 とPEPT2 が発現し，機能していると考えられてい る. ${ }^{81-83)}$ 一方，有機アニオンの分泌については, Mrp2 ${ }^{84)}$ を除き，詳細な分子機構はまだよく分かっ ていない。ICC の結果は S3 部位のPEPT2 が, AMPC の再吸収に機能していることを示唆する. また，投与 3 時間で AMPC は遠位尿細管と集合管 細胞にも高濃度が分布した。その分布パターンは GM でみられたように [Fig. 4(a)]，管の隣同士の 細胞でも，一方は抗体と強く反応するが，他方はほ とんど反応しなかった。事実，これらの部位の細胞 は, 形態学的に principal cell と intercalated cell か ら構成され，生理機能が異なることが知られてい る. ${ }^{85)}$

\section{9.おわりに}

抗生物質の ICC 研究から, 薬物特有の組織・細 胞・分布・蓄積パターンが示された。 DX, DR, ER では, 薬物の微小な化学構造の差異が, その臓器蓄 積性に大きく影響した。ICC 法は, 薬物の臓器毒 性に関する細胞レベルの研究に極めて有用であつ た。また，薬物の組織・細胞分布研究は，薬物の specific transporters の役割解明に有用であった。今 後の研究には, 免疫電子顕微鏡学的研究が不可欠で ある．今後，小動物での抗生物質の経時的な組織・ 細胞分布地図ができれば，臨床分野での感染症治療 にも，有用な情報を提供すると思われる．結論的に， ICC 法は今後, 広範な薬物の薬物動態学研究に有
用であると思われる. 最後に, 薬学出身者で, 組織 学を指向する研究者は稀であるが，本稿が契機とな って, 薬物動態学と組織学との融合領域に興味を抱 く研究者が出てくれば幸いである.

謝辞本研究は, 崇城大学・生物生命学部・応 用生命科学科・第一講座によって行われたものであ り，進 正志准教授の成果でもあります。本研究に 御協力頂いた大学院生， 4 年生に感謝します。ま た，本稿執筆にあたりまして，種々ご指導頂きまし た長崎大学名誉教授・北川常広先生，鶴 大典先 生，故・瀬戸口孝夫先生に心よりお礼申し上げます。

\section{REFERENCES}

1) Peng L., Nimni M. E., J. Pharm. Pharmacol., 51, 1135-1141 (1999).

2) Mountfield R. J., Kiehr B., John B. A., Drug Metab. Dispos., 28, 503-513 (2000).

3) Fujiwara K., Takatsu H., Tsukamoto K., $J$. Histochem. Cytochem., 53, 467-474 (2005).

4) Fujiwara K., Masuyama Y., Histochem. Cell Biol., 104, 309-316 (1995) .

5) Fujiwara K., Masuyama Y., Kitagawa T., Histochem. Cell Biol., 106, 465-471 (1996).

6) Fujiwara K., Bai G., Kitagawa T., Tsuru D., J. Histochem. Cytochem., 46, 1321-1328 (1998).

7) Shin M., Hirokawa K., Fujiwara K., Histochem. Cell Biol., 125, 369-375 (2006).

8) Fujiwara K., Kitagawa T., Inoue Y., Alonso G., Histochem. Cell Biol., 107, 39-45 (1997).

9) Fujiwara K., Bai G., Tamura C., Tsuru D., J. Histochem. Cytochem., 47, 1031-1038 (1999).

10) Fujiwara K., Karasuyama M., Murata I., Tanabe T., Yabuuchi M., Tsuru D., Cell Tissue Res., 306, 295-300 (2001).

11) Fujiwara K., Shin M., Hougaard D. M., Larsson L.-I., Histochem. Cell Biol., 127, 69-77 (2007).

12) Ohara K., Shin M., Larsson L.-I., Fujiwara K., Histochem. Cell Biol., 127, 603-608 (2007).

13) Koreeda A., Yonemitsu K., Kohmatsu H., Mimasaka S., Ohtsu Y., Oshima T., Fujiwara K., Tsunenari S., Arch. Toxicol., 81, 471-478 (2007).

14) Ohara K., Shin M., Nakamuta H., Larsson 
L.-I., Hougaard D. M., Fujiwara K., Histochem. Cell Biol., 128, 285-290 (2007).

15) Shin M., Larsson L.-I., Hougaard D., Fujiwara K., Cell Tissue Res., 337, 429-438 (2009)

16) Shin M., Matsunaga H., Fujiwara K., Histochem. Cell Biol., 133, 677-682 (2010).

17) Fujiwara K., Shin M., Miyazaki T., Histochem. Cell Biol., 135, 93-101 (2011).

18) Fujiwara K., Shin M., Matsunaga H., Saita T., Larsson L.-I., Antimicrob. Agents Chemother., 53, 3302-3307 (2009).

19) Fujiwara K., Shin M., Miyazaki T., Maruta Y., Antimicrob. Agents Chemother., 55, 6271 (2011).

20) Fujiwara K., Yasuno M., Kitagawa T., Cancer Res., 41, 4121-4126 (1981).

21) Fujiwara K., Saikusa H., Yasuno M., Kitagawa T., Cancer Res., 42, 1487-1491 (1982).

22) Fujiwara K., Nakamura N., Kitagawa T., Saito A., Hara K., Cancer Res., 44, 4172-4176 (1984).

23) Fujiwara K., Saita T., Takenawa N., Matsumoto N., Kitagawa T., Cancer Res., 48, 915-920 (1988).

24) Fujiwara K., Araki M., Kitagawa T., Inoue Y., Histochemistry, 99, 477-483 (1993).

25) Moran R., Darzynkiewicz Z., Ataiano-Coico L., Melamed M. R., J. Histochem. Cytochem., 33, 821-827 (1985).

26) Sugihara H., Hattori T., Fukuda M., Histochemistry, 85, 193-195 (1986).

27) Hayashi A., Koike M., Matsunami M., Hoshino T., J. Histochem. Cytochem., 36, 511-514 (1988)

28) Matute C., Streit P., Histochemistry, 86, 147157 (1986).

29) Madl J. E., Larson A. A., Beitz A. J., J. Histochem. Cytochem., 34, 317-326 (1986).

30) Panula P., Yang H.-Y., Costa E., Proc. Natl. Acad. Sci. USA, 81, 2572-2576 (1984).

31) Chagnaud J.-Y., Mons N., Tuffet S., Grandier-Vazeilles X., Geffard M., J. Neurochem., 49, 487-494 (1987).

32) Fujiwara K., Kaminishi Y., Inoue Y., Yabuuchi M., Brain Res., 806, 210-218 (1998).

33) Blum R. H., Cancer Chemother. Rep., 6, 247251 (1975).

34) Arcamone F., Penco S., Vigevani A., Redaelli
S., Franchi G., DiMarco A., Casazza A. M., Dasdia T., Formelli F., Necco A., Soranzo C., J. Med. Chem., 18, 703-707 (1975).

35) Di Marco A., Gaetani M., Dorigotti L., Soldati M., Bellini O., Tumori, 49, 203-217 (1963).

36) Gottesman M. M., Pastan I., Annu. Rev. Biochem ., 62, 385-427 (1993).

37) Hussain I., Kellet L., Affleck J., Shepherd J., Boyd R., Cell Tissue Res., 307, 139-142 (2002).

38) Katsura T., Inui K., Drug Metab. Pharmacokinet., 18, 1-15 (2003).

39) Thakker N. S., Potten C. S., Cancer Res., 53, 2057-2060 (1993).

40) Thakker N. S., Potten C. S., Biochem. Pharmacol., 43, 1683-1691 (1992).

41) Bloom W., Fawcett D. W., "Textbook of Histology,', 11th ed., W. B. Saunders Company, Philadelphia, 1986, pp. 641-671.

42) Cotsarelis G., Sun T. T., Lavker R. M., Cell, 61, 1329-1337 (1990).

43) Hoffman R. M., Nat. Biotechnol., 18, 20-21 (2000)

44) Taylor G., Lehrer M. S., Jensen P. J., Sun T. T., Lavker R. M., Cell, 102, 451-461 (2000).

45) Van Scoot E. J., Ekel T. M., J. Invest. Dermatol., 31, 281-287 (1958).

46) Kligman A. M., J. Invest. Dermatol., 33, 307316 (1959).

47) Pinkus H., J. Dermatol., 5, 93-101 (1978).

48) Kerr J. F., Wyllie A. H., Currie A. R., Br. J. Cancer, 26, 239-257 (1972).

49) Kondo Y., Kanzawa T., Sawaya R., Kondo S., Nat. Rev. Cancer, 5, 726-734 (2005).

50) Levine B., Yuan J., J. Clin. Invest., 115, 2679 -2688 (2005)

51) Yokoyama T., Miyazawa K., Naito M., Toyotake J., Tauchi T., Itoh M., You A., Hayashi Y., Georgescu M.-M., Kondo Y., Kondo S., Ohyashiki K., Autophagy, 4, 629-640 (2008).

52) Thiebaut F., Tsuruo T., Hamada H., Gottesman M. M., Pastan I., Willingham M. C. Proc. Natl. Acad. Sci. USA, 84, 7735-7738 (1987).

53) Sugawara I., Kataoka I., Morishita Y., Hamada H., Tsuruo T., Itoyama S., Mori S., Drug Matab. Dispos., 17, 98-105 (1989).

54) Meijer D. K. F., Smit J. W., Muller M., $A d v$. Drug Deliv. Rev., 25, 159-200 (1997). 
55) Kumimoto Y., Gatmaitan Z., Hsu J., Arias I. M., J. Biol. Chem., 264, 11693-11698 (1989).

56) Gottesman M. M., Pastan I., Annu. Rev. Biochem., 62, 385-427 (1993).

57) Schaub T. P., Kartenbeck J., Konig J., Vogel O., Witzgall R., Kriz W., Keppler D., J. Am. Soc. Nephrol., 8, 1213-1221 (1997).

58) Bergeron M. G., Moris M., Kuehn C., Silverblatt F. J., Antimicrob. Agents Chemother., 32, 1359-1364 (1987).

59) Silverblatt F., Kuehn C., Kidney Int., 15, 335345 (1979).

60) Beauchamp D., Gourde P., Bergeron M. G., Antimicrob. Agents Chemother., 35, 21372179 (1991).

61) Wedeen R. P., Batuman U., Cheeks C., Marquet E., Sobel H., Lab. Investig., 48, 212-223 (1983).

62) Parsons P. P., Garland H. O., Harpur E. S., Br. J. Pharmacol., 130, 441-449 (2000).

63) Sikic B. I., Siddik Z. H., Gram T. E., Cancer Treat. Rep., 64, 659-668 (1980).

64) Umezawa H., Prog. Biochem. Pharmacol., 11, 18-27 (1976).

65) Inui K., Masuda S., Saito H., Kidney Int., 58, 944-958 (2000).

66) Dantzig A. H., Bergin K., Biochem. Biophys. Res. Commun., 155, 1082-1087 (1988).

67) Shen H., Smith D. E., Yang T., Huang Y. G., Schnermann J. B., Brosius F. C. III, Am. J. Physiol. Renal Physiol., 276, F658-F665 (1999).

68) Yang C. Y., Dantzig A. H., Pidgeon C., Pharm. Res., 16, 1331-1343 (1999).

69) Barza N., Brush J., Bergeron N. C., Kemmotsu O., Weinstein L., J. Infect. Dis., 131 (Suppl.), S86-S97 (1975).

70) Yabuuchi H., Tamai I., Morita K., Kouda T., Miyamoto K., Takeda E., Tsuji A., J. Pharmacol. Exp. Ther., 286, 1391-1396 (1998).

71) Bergwerk A. J., Shi K., Ford A. C., Kanai N., Jacquemin E., Burk R. D., Bai S., Novikoff P. R., Stieger B., Meier P. J., Schuster V. L., Wolkoff A. W., Am. J. Physiol. Gastrointest. Liver Physiol., 271, G231-G238 (1996).
72) Bodo A., Bakos E., Szeri F., Varadi A., Sarkadi B., J. Biol. Chem., 278, 23529-23537 (2003).

73) Chong S. S., Kozak C. A., Liu L., Kristjansson K., Dunn S. T., Bourdeau J. E., Hughes M. R., Am. J. Physiol., 268, F1038-F1045 (1995).

74) Hagenbuch B., Stieger B., Foguet M., Lübbert H., Meier P. J., Proc. Natl. Acad. Sci. USA, 88, 10629-10633 (1991).

75) Tsuji A., Terasaki T., Tamai I., Takeda K., J. Pharmacol. Exp. Ther., 253, 315-320 (1990).

76) Ito K., Koresawa T., Nakano K., Horie T., Am. J. Physiol. Gastrointest. Liver Physiol., 287, G42-G49 (2004).

77) Sathirakul K., Suzuki H., Yasuda K., Hanano M., Tagaya O., Horie T., Sugiyama Y., J. Pharmacol. Exp. Ther., 265, 1301-1312 (1993).

78) Inui K., Terada T., "Membrane Transporters as Drug Targets, Dipeptide transporters,", eds. by Amidon G. L., Sadée W., Kluwer Academic/Plenum Publishers, New York, 1999, pp. 269-288.

79) Apiwattanakul N., Sekine T., Chairoungdua A., Kanai Y., Nakajima N., Sophasan S., Endou H., Mol. Pharmacol., 55, 847-854 (1999).

80) Tojo A., Sekine T., Nakajima N., Hosoyamada M., Kanai Y., Kimura K., Endou H., J. Am. Soc. Nephrol., 10, 464-471 (1999).

81) Inui K., Okano T., Takano M., Saito H., Hori R., Biochim. Biophys. Acta, 769, 449-454 (1984).

82) Shen H., Smith D. E., Yang T., Huang Y. G., Schnermann J. B., Brosius F. C. III, Am. J. Physiol. Renal. Physiol., 276, F658-F665 (1999) .

83) Leibach F. H., Ganapathy V., Annu. Rev. Nutr., 16, 99-119 (1996) .

84) Schaub P. P., Kartenbeck J., Konig J., Vogel O., Witzgall R., Kriz W., Keppler D., J. Am. Soc. Nephrol., 8, 1213-1221 (1997).

85) Madsen K. M. R., Tisher C. C., Am. J. Physiol., 250, F1-F15 (1986). 